\title{
CULTURE'S IMPACT ON ENTREPRENEURSHIP \& INTERACTION EFFECT OF ECONOMIC DEVELOPMENT LEVEL: AN 81 COUNTRY STUDY
}

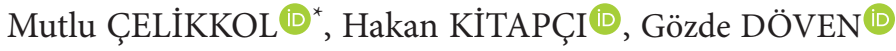 \\ Institute of Social Sciences, Gebze Teknik Üniversitesi, Kocaeli, Turkey \\ Received 19 December 2018; accepted 15 April 2019
}

\begin{abstract}
This research has two aims. The first one is to determine how and to what extent the national cultural characteristic of a country plays a role in her entrepreneurship success. The second one is to determine whether culture and economic development levels interact with each other on influencing entrepreneurship success. A consecutive five-year longitudinal study, covering 81 countries is conducted. Longitudinal Random Effect Regression Analysis is used to determine the effects of culture on entrepreneurship rates. Data regarding the cultural dimensions indexes of the countries is obtained from Geert Hofstede website and the entrepreneurship rates from the annual reports of the Global Entrepreneurship and Development Institute. The interaction effect of cultural dimensions and economic development levels on entrepreneurship is analyzed by treating the economic development level is the interacting variable between cultural dimensions and entrepreneurship rates. Economic development levels of the countries are measured by GDP per capita, figures obtained from the World Bank. The findings are that the cultural dimensions Individualism, Long Term Orientation, and Indulgence vs. Restraint influence the entrepreneurship rate in a supportive manner, whereas Masculinity's impact is in a rendering manner. Other dimensions seem to have no significant effect. Although relevant cultural dimensions do interact with economic development levels, their interaction effects are small. This study has several unique contributions to the entrepreneurship literature, such as its longitudinal nature, using all Hofstede Dimensions, applying a very comprehensive entrepreneurship measurement scale, its huge sample size and containing an interactive analysis of culture and economic development level which is very rare in the literature.
\end{abstract}

Keywords: cross-cultural study, interaction of culture \& economy, entrepreneurship, Hofstede dimensions.

JEL Classification: L26, M13, O57, R11.

\section{Introduction}

The late $20^{\text {th }}$ century has witnessed an immense change in the course of economic history. This change has shaken all national economies of the World; the centrally-planned econo-

${ }^{\star}$ Corresponding author. E-mail: mcelikkol@gtu.edu.tr 
mies of Eastern and Central Europe have gradually collapsed, and huge companies of the free-market Western economies have gone into a process of downsizing and reorganizing towards smaller, more energetic and flexible young firms. This new economic period is called "entrepreneurial economy" (Audretsch, Carree, \& Thurik, 2001), and this period has caused radical changes in social, economic, cultural and technological environments (Coulibaly, Erbao, \& Mekongcho, 2018). Subsequent research has shown that these changes do not occur in all developed countries concurrently and to the same extent (Audretsch, Thurik, Verheul, \& Wennekers, 2002). The entrepreneurial success rate of the countries considerably varies across the world (Wennekers, 2006; Freytag \& Thurik, 2007). Cross-country entrepreneurial research can, therefore, shed light on such variations.

Countries differ remarkably in their level of entrepreneurial activity (Minniti, Bygrave, \& Autio, 2005; Kelley, Singer, \& Herrington, 2012; Bogatyreva, Edelman, Manolova, Osiyevskyy, \& Shirokova, 2019) and these variations are stable (Uhlaner \& Thurik, 2007). The question of why some regions or countries are more entrepreneurial than others is a subject of high importance. The reason is obvious. Entrepreneurship has been considered as the primary determinant of innovation, technological progress, job creation, and economic dynamism and growth (Dheer, 2017; Kuratko, 2003; Schumpeter, 1934). Entrepreneurship has never been as important as today (Galvão, Mascarenhas, Gouveia Rodrigues, Marques, \& Leal, 2017).

Despite the extensive research on the variability of entrepreneurial success across countries, variations among nations have not been adequately clarified by conventional economic and political approaches (Davidsson \& Wiklund, 1997; Frederking, 2004). National culture has been ascribed to a considerable amount of such variations. Huntington (1997) argues that national cultures upon which civilizations are established out-rank current technological advances and thus providing lasting variations among cultures. Therefore, it can be assumed that culture can contribute to uncovering the variety of entrepreneurial success levels among nations (Hofstede et al., 2004, p. 104).

How national culture impacts the degree of entrepreneurial activity is a very old research question in entrepreneurship field and goes back to the studies of scholars from various fields (e.g., Schumpeter, 1934; Weber, 1930; McClelland, 1961). Although prior research has demonstrated a link between entrepreneurial activity and national culture, scholars have not reached an agreement on the explanation of the variations of entrepreneurial activity across cultures (Shane, 1996; McDougall \& Oviatt, 2000; McGrath, MacMillan, \& Scheinberg, 1992).

The hypothesized connection between culture and entrepreneurship activity has not been sufficiently established (see Hayton, George, \& Zahra, 2002). Many questions are still waiting to be answered. There is no theoretical basis for the explanations beyond scattered approaches and partial connections. "The Black Box" of entrepreneurship is not opened yet (Fiet, 2002).

This paper aims to attempt to clarify some equivocal issues in the relevant entrepreneurship literature. Firstly, entrepreneurship is a multidimensional concept (Bula, 2012) and measuring it by the number of new ventures established (see Gartner, 1988; Shane, 2008) does not reflect the whole picture of it. It is argued that entrepreneurial initiatives can also emerge within organizations (Kuratko, 2007) i.e., in the form of corporate entrepreneurship (see Morris, Kuratko, \& Covin, 2010). Additionally, entrepreneurship is not restricted to 
business activities and may take different forms, including social entrepreneurship (Nicolás \& Fernández-Laviada, 2018; Mair \& Marti, 2006). A broader and inclusive conceptualization of entrepreneurship is needed to cover all its aspects.

Second, earlier studies have used certain aspects of culture to explain the entrepreneurial activity. Since culture can be thought as a system comprised of common values to members of the society (Hofstede, 2001), all components of this system, i.e., all cultural dimensions, should be included in the analysis with a holistic view.

Third, as Cacciotti and Hayton (2017, p. 407) have argued, the theoretical approach should include the time and also the level of economic development. Entrepreneurial research should be longitudinal in order to avoid temporal or conjectural fluctuations. The prosperity levels of the countries should also be taken into account since studies have furnished empirical evidence on the interaction effects (Wennekers, Van Wennekers, Thurik, \& Reynolds, 2005).

Finally; an absolute lack of clarity may come out from the constraints in the methodology of the previous empirical cross-cultural studies. Many studies were conducted with a limited sample size of countries. Furthermore, sometimes the unit of analysis was a firm, the entrepreneur himself, or students instead of a nation. Most importantly, the measurement of entrepreneurial success has been usually the number of new ventures which may not be reliable data for some countries (see Hayton \& Cacciotti, 2013).

This research attempts to eliminate above- mentioned gaps by analyzing 81 countries' entrepreneurial success for five continuous years, using the most inclusive definitions and measurement scales, with the new cultural dimensions recently added to the literature and taking into account the interaction effects. To achieve this goal. Longitudinal Random Effect Regression Analysis is used to determine the influence of culture on entrepreneurship rates. Cultural Dimensions Indexes data are obtained from Geert Hofstede website and the entrepreneurship rates from the Global Entrepreneurship and Development Institute publications. The interaction effect of cultural dimensions with economic development levels on entrepreneurship is analyzed by using the PROCESS ${ }^{\circ}$ macro for SPSS, where economic development levels of the countries are measured by GDP per capita, figures are adopted from World Bank Databases.

This study is organized in the following way. In the next section, a conceptual framework is developed by performing a systematic analysis of scientific literature. Section 2 presents the entrepreneurship success rate measurement method. Section 3 is devoted to the development of empirical hypotheses. Section 4 covers the methodology, the data, variables, and data analysis. The results of the regression and interaction effect analyses are presented in Section 5. Finally, in Section 6, the main results of the study are discussed.

\section{Influence of national culture on entrepreneurship}

It is widely accepted that culture is a significant determinant of economic growth. Landes (1998, p. 516) indicates that the history of economic development proves the impact of culture. Weber (1930) was the first author to write about the relation between culture and economy (Harutyunyan \& Özak, 2017). Up to today, a remarkable body of scholarly research 
has been accumulated whose results suggest that national cultures significantly influence productivity, inventiveness, and innovation of the countries (Shane, 1992, 1993; Shane, Venkataraman, \& MacMillan, 1995). Also, at the firm level, Hofstede (2001) points out that national culture influences different kinds of economic management behavior.

Entrepreneurship and its social ground go back Weber (1930) and Schumpeter (1934). They contend that the sources of entrepreneurial attitude and behaviors exist in the society's socio-cultural structure and value systems. Cultural and social norms are claimed to be the primary factors for the different levels of entrepreneurial activity across the nation (Minniti, Bygrave, \& Autio, 2006) and a significant number of studies point out the particular relations between cultural indicators and entrepreneurial activity (Autio, Pathak, \& Wennberg, 2013).

National culture exerts its influence mainly at two levels, one is on the individual, and the other one is on the societal level. In this study, institutions are approached as the products of national cultures since national culture and its values shape the structures of social, political and technical systems of the society which support or render entrepreneurship (Coulibaly et al., 2018). As Shapero and Sokol contend that the socio-cultural constituents entering into the embodiment of entrepreneurship are mostly seen at a person's own value system (1982, p. 83). A supportive culture with values, encouraging entrepreneurial orientations can shape an individual's cognitive schema and attitudes towards entrepreneurship (Krueger, Liñán, \& Nabi, 2013). This encouraging set of values and beliefs influence the way individuals define their behaviors in terms of basic entrepreneurial traits, including risk-taking, productivity, independent judgment, and desire to become an entrepreneur (Hofstede, 2010; Mueller \& Thomas, 2001; Hayton et al., 2002; Kreiser, Marino, Dickson, \& Weaver, 2010) which is a complex process (Laffranchini et al., 2018). There is a substantial body of studies investigating the influence of culture on behaviors and attitudes related to entrepreneurship (e.g., Soares, Farhangmehr, \& Shoham, 2007; Baughn \& Neupert, 2003; Hechavarria \& Reynolds, 2009; Suddle, Beugelsdijk, \& Wennekers, 2010; Tiessen, 1997) and the findings of the studies suggest that national culture consistently manipulates various entrepreneurial attitudes.

Since culture can be defined as a complex social structure, consisting of knowledge, values, beliefs, art, morality, customs and habits possessed by the majority of the members of the society (Soares et al., 2007). Defined in this way, culture is a mental model ( $\mathrm{Au}, \mathrm{Han}$, \& Chung, 2018), members of a society share. A supportive culture is likely to form a basis for the legitimacy of entrepreneurial behavior and this social legitimization makes the entrepreneurial career more valued, and a supportive ecology is created. Therefore, more people will devote their efforts towards entrepreneurship (Etzioni, 1987). To sum up, culture not only impacts the behavior of the people but also has an important influence on the economic functioning of society (Dheer, 2017).

What is known that there is a link between national culture and entrepreneurial success, but questions about how and to what extent culture impacts entrepreneurial activities are not entirely answered (Caccioti \& Hayton, 2017). The results of cross-country studies examining the influence of cultural dimensions are most of the time confusing and contradictory (Hayton \& Cacciotti, 2013). It is a well- known fact that both entrepreneurship and culture are elusive, multi-dimensional phenomena which make them difficult to define. Furthermore, there is no agreed definition of the social institutions influencing entrepreneurial activity 
which makes almost impossible to compare the studies (Bula, 2012; Hofstede, 2001; House, Hanges, Javidan, Dorfman, \& Gupta, 2004; Ralston, Holt, Terpstra, \& Kai-Cheng, 1997; Hui $\&$ Triandis, 1986). In addition to this, studies using time and economic development level as variables are scarce and this makes it almost impossible to draw a solid conclusion, regarding the unique factor impact of either type of element (Davidsson \& Winklund, 1997). And usually, there are apparent methodological limitations regarding the numbers of the countries, analysis level, and measurement conceptualizations.

\section{Global entrepreneurship and Development Institute}

Global Entrepreneurship and Development Institute (GEDI) is a non-profit organization which enhances insight into the relations among entrepreneurial activity, economic development and wealth. It was established by an initiative of scholars from the LSE, George Mason University, University of Pécs and Imperial College London. The main financial funding source for the researches of GEDI is the European Union, The World Bank, and some various corporations and banks (Acs, Szerb, \& Lloyd, 2018).

GEDI basically defines an entrepreneur as a person who has the perception to detect and evaluate an innovative opportunity (products and processes) and present the innovation to its potential consumers. This definition is highly similar to the description of Shane and Venkataraman (2000). GEDI definition of entrepreneurship covers only the "opportunity driven entrepreneurship", which positively influences economic development (Acs et al., 2018).

GEDI assesses the entrepreneurial success of the countries by an index published annually. The GEDI Index covers three crucial determinants of entrepreneurship, named as 3A's, entrepreneurial attitudes, abilities, and aspirations. Entrepreneurial Attitudes sub-index concerns with how a country thinks about entrepreneurship and asks questions like "Is it socially legal or legitimate?”. Entrepreneurial Abilities sub-index is about abilities and competencies. The third sub-index Entrepreneurial Aspirations is about desires, ambitions, and motivations. The 3 A's are constituted of 14 variables. These 14 variables have an individual and constitutional component, which correspond to the micro and macro aspects of entrepreneurship (Acs et al., 2018). The arithmetic mean of three sub-indexes is the country's overall entrepreneurial index. This approach is followed throughout this paper, and entrepreneurial success may be viewed as the harmonious combination of abilities, aspirations and attitudes since the personal traits, motivations, desires, the socio-cultural and institutional environments of the individual are among the main factors influencing entrepreneurship (Hofstede, 2011; Hayton \& Caccioti, 2013; McGrath et al., 1992; Amiri \& Mariami, 2012). GEDI methodology has been approved by academic peers and extensively disclosed in the media, including Forbes, The Economist, Financial Times, The Wall Street Journal and (Acs et al., 2018).

\section{Hofstede's cultural dimensions and hypothesis development}

Empirically identifying the different types of culture is the first step in designing a methodology in culture-based research. Among the different conceptualizations of culture (e.g. Bond et al., 2004; Hofstede, 1980; House et al., 2004; Inglehart, 1997; Schwartz, 1994). Hofstede’s 
conceptualization of culture has received the widest acceptance (Kirkman et al., 2006). In the field of culture and entrepreneurship research, Hofstede $(1980,2001)$ cultural dimensions approach is certainly the one most commonly adopted (Pinillos \& Reyes, 2011).

Hofstede's conceptualization of culture consists of six dimensions which are; Power Distance, Individualism, Masculinity, Uncertainty Avoidance, Long Term Orientation, and Indulgence vs. Restraint (Hofstede, 2001; Hofstede et al., 2010). All these six dimensions are used simultaneously as independent variables in this study.

\subsection{Power distance}

Power Distance indicates the degree of acceptance of unequal distribution of power and authority by the relatively less powerful individuals in a culture (Hofstede, 2001, p. 98). It shows the level of dependence or independence of people in a society. Power Distance is the measure of what extent inequality is accepted within a culture (Carayannis, 2013, p. 635).

Earlier studies examining the association between Power Distance and entrepreneurship have strongly argued that Power Distance is not conducive to entrepreneurship (e.g. Hofstede, 2001; Hayton et al., 2002; Mitchell et al., 2000; Shane, 1992). This argument based on the assumption that in countries which have a high level of power distance, less powerful individuals may regard entrepreneurship as an area restricted only to a higher class, so they are not alert for the opportunities. Additionally, they may not have the necessary skills and access to resources. There are contradictory arguments about the impact of Power Distance on entrepreneurship (i.e. Mc Grath et al., 1992; Hofstede et al., 2004), but among them, the Hofstede theory which states that Power Distance and desire for autonomy is negatively related (Hofstede, 2001) is more preferred. Since entrepreneurs are achievement-oriented, independent in nature individuals, the hypothesizes are arranged as follows:

$H_{1 a}$ : Power Distance negatively influences entrepreneurial attitudes;

$H_{1 b}$ : Power Distance negatively influences entrepreneurial abilities;

$H_{1 c}:$ Power Distance negatively influences entrepreneurial aspirations;

$H_{1 d}$ : Power Distance negatively influences overall entrepreneurial success.

\subsection{Individualism and collectivism}

Individualism is the degree of the looseness of the bond between the members of the society. In individualistic cultures, individuals are expected to take care of themselves or their family alone. Collectivism, on the other hand, refers to a society whose members are part of a united, cohesive group that protects from birth onwards in exchange for indisputable obedience. Individualism stresses self-sufficiency and self-control. People in individualistic cultures feel proud of their accomplishments and are motivated by their interests and objectives. On the other pole, individuals in collectivist cultures identify themselves with the group which provides safety to the members, encourages them to share and cooperate (Carayannis, 2013), and shape their behavior in accordance with group values (Bogatryeva, 2019).

Individualism, in many types of research examining the impact of culture on entrepreneurship, appears to be strongly facilitating entrepreneurship (Mueller \& Thomas, 2001). This argument explains that individualistic societies create a more favorable environment for 
entrepreneurship since dominant cultural values are more consistent with entrepreneurial inclinations. Therefore, entrepreneurship is perceived as more proper and appropriate (Morris et al., 1993; Pinillos \& Reyes, 2011). The positive influence of individualism on entrepreneurship argument is supported by some empirical studies (i.e., McGrath et al., 1992; Mueller \& Thomas, 2001), but there are also contradictory results in which collectivism supports entrepreneurship (i.e., Acs, Audretsch, \& Evans, 1992; Wu, 2007). Recent studies, therefore, show that the effect of individualism on entrepreneurship is not certain.

In an interesting study on the impact of individualism by Pinillos and Reyes (2011), the authors argue that if the economic development level in a country is low or medium, individualism negatively influences entrepreneurship, and positively influence when the development is high. This study is an example of the interaction effects of economic development and culture on entrepreneurial success.

Individualistic cultures encourage entrepreneurship by emphasizing the identity of an individual rather than his/her society and therefore supporting typical characteristics of entrepreneurs such as high level of self- confidence, initiative, and courage. On the individual level, entrepreneurs struggle for high achievement (McClelland, 1961) and have a relatively high level of internal locus of control (Mueller \& Thomas, 2001). Thus, it is hypothesized as follows:
$\mathrm{H}_{2 a}$ : Individualism positively influences entrepreneurial attitudes;
$\mathrm{H}_{2 b}$ : Individualism positively influences entrepreneurial abilities;
$\mathrm{H}_{2 c}$ : Individualism positively influences entrepreneurial aspirations;
$H_{2 d}$ : Individualism positively influences overall entrepreneurial success.

\subsection{Masculinity and feminity}

Masculinity is the degree of separation of gender roles in society. In masculine cultures, the roles are clean-cut. Men are supposed to be confident, decisive, vigorous and involved in material things, while women are supposed to take care of the home- issues, the quality of daily life, to be prudent and caring. On the other pole, in feminine cultures the separation of the gender roles is not so clear, gender roles are sometimes overlaid. Masculinity and Feminity dimension indicates a culture's approach to success, appreciation, competitiveness, and affiliation. Cultures with a high level of masculinity tend to be oriented toward wealth, career, independence, and leave for work, whereas, in cultures with a low level of masculinity, individuals prefer to work to live with an emphasis on relationships and social interactions (Hofstede, 2001; McGrath et al., 1992). In the majority of studies on culture and entrepreneurship, researchers have hypothesized that the ideal entrepreneur would/should be high on masculinity (Hayton et al., 2002; Hofstede, 1980; Shane, 1992). This assumption has some empirical evidence (McGrath et al., 1992; Ahl, 2006; Gupta et al., 2009). On the other hand, Wu (2007) and Osoba (2009) claim that masculinity and entrepreneurial activity are not significantly related.

High-masculine cultures support entrepreneurial behavior from members of such societies are educated to be independent, strong, ambitious and they see failure as an indication of moderateness. In this type of cultures, achievement is associated with wealth and position 
with self-assertiveness whereas successful career and independence being the dominant values. In feminine societies, on the other hand, it is highly possible that economic development is not the ultimate goal of society. However, a cordial, safe environment and cooperation are more important in such societies. With these arguments, it is hypothesized as follows:
$H_{3 a}$ : Masculinity positively influences entrepreneurial attitudes;
$H_{3 b}$ : Masculinity positively influences entrepreneurial abilities;
$\mathrm{H}_{3 c}$ : Masculinity positively influences entrepreneurial aspirations;
$H_{3 d}$ : Masculinity positively influences overall entrepreneurial success.

\subsection{Uncertainty avoidance}

Uncertainty Avoidance indicates the degree of fear or anxiety, perceived by the member of a society in uncertain situations. In cultures with a high level of uncertainty avoidance, members of society feel uncomfortable when dealing with ambiguity and perceive uncertainty as a threat (Au \& Chung, 2018). As a result, preferences lean toward greater systems with clear rules and procedures. Conversely, in cultures with low uncertainty, members are relatively more at ease with unfamiliar situations (Hofstede, 2001).

Tolerance of uncertainty and risk-taking is theoretically well connected. (Kreiser et al., 2010). Low uncertainty avoidance suggests a greater eagerness to set up unknown businesses (Hofstede, 2001, p. 164). Members of a society tend to be more entrepreneurial if the cultural atmosphere encourages the acknowledgment of uncertainty and risk. This argument has several empirical supports (e.g., Kreiser et al., 2010; McGrath et al., 1992; Osoba, 2009), however, there are some contradictory results as well (i.e., Acs et al., 1992; Wennekers et al., 2007). The opposite argument is that the restrictive business environment in high uncertainty avoidance countries could push an individual towards self-employment with entrepreneurship being the way to which innovative employee may attain their objectives (Wennekers et al., 2007).

Members of a low uncertainty avoidance culture are more likely to look for innovative ways of doing things, and they tend to take risks and take advantage of available opportunities which are identified in the environment they live in (Busenitz \& Lau, 1996). Thus, a supportive ecology is created where the individuals will likely be more enthusiastic to become entrepreneurs. Thus, it is proposed that:

$H_{4 a}:$ Uncertainty Avoidance negatively influences entrepreneurial attitudes;
$H_{4 b}:$ Uncertainty Avoidance negatively influences entrepreneurial abilities;
$H_{4 c}:$ Uncertainty Avoidance negatively influences entrepreneurial aspirations;
$H_{4 d}:$ Uncertainty Avoidance negatively influences overall entrepreneurial success.

\subsection{Long term orientation}

Long Term Orientation, also known as Confucian Dynamism, encourage future-oriented virtues such as perseverance and thrift whose rewards hoped to be cultivated in the future. On the contrary Short Term Orientation emphasizes the virtues which are linked to the past and present, such as respect for customs, habits and pleasing social duties (Hofstede, Hofstede, \& Minkov, 2010, p. 239). This dimension refers to the preferences leaning towards either a forward-looking perspective or a more historical and traditional perspective. 
Some authors argue that this dimension and its Confucian cultural value content is strongly associated with the impressive economic development of South Asian countries starting in the second half of the last century (Hofstede, 2011; Hofstede \& Bond, 1988; Ralston et al., 1997). Empirical support is not available on the impact of Long Term Orientation on entrepreneurship either positively or negatively. Some authors argue that there is a strong influence of this dimension on innovation (e.g., Van Everdingen \& Waarts, 2003; Lin, 2009; Allred \& Swan, 2004) which is a critical aspect of entrepreneurship. As entrepreneurship is a challenging, risky process oriented towards future goals and the entrepreneurs tend to have aspirations, vision, optimism, foresight, and imagination (Swierczek \& Quang, 2004; Amiri \& Marimaei, 2012), it is hypothesized that:
$H_{5 a}$ : Long Term Orientation positively influences entrepreneurial attitudes;
$H_{5 b}$ : Long Term Orientation positively influence entrepreneurial abilities;
$H_{5 c}$ : Long Term Orientation positively influence entrepreneurial aspirations;
$H_{5 d}$ : Long Term Orientation positively influences overall entrepreneurial success.

\subsection{Indulgence vs. restraint}

This sixth and newest dimension reflects the determinants of a measure of happiness or what the psychologists call "subjective well-being." Indulge is the degree of importance given by the members of the society on personal control of life, fulfilling human desires, enjoyment, and entertainment in daily life. It is about how personal life control is perceived by the members of the society. On the Indulgence pole of this dimension individuals feel comfortable when they spend money and entertain themselves in social activities or alone, whereas on the Restraint pole, various social norms and prohibitions restrain one's actions. Fulfilling human desires or entertaining activities together with a perception of life based on happiness search are looked at as somehow inappropriate (Hofstede, 2010, p. 281).

The literature suggests that there is a link between Individualism and the idea of happiness. Happiness is associated with a perception of control over one's life and a sense of freedom (Minkov, 2009, pp. 113-115). Since entrepreneurs have a high internal locus of control, personal value systems, desire to be economically independent, capacity for enjoyment and a pleasant personality (Swierczek \& Quang, 2004; Amiri \& Marimaei, 2012), it is stated that:

$H_{6 a}:$ Indulgence positively influences entrepreneurial attitudes;

$H_{6 b}$ : Indulge positively influences entrepreneurial abilities;

$H_{6 c}:$ Indulgence positively influences entrepreneurial aspirations;

$H_{6 d}$ : Indulgence positively influences overall entrepreneurial success.

There are arguments on the interaction of cultural dimensions with the economic development level on entrepreneurship (e.g. Pinillos \& Reyes, 2011; Wennekers et al., 2005). But, the theory is weak and empirical studies are rare, therefore, the interaction effect analysis is run without any hypotheses. 


\section{Research methodology}

\subsection{Sample and data}

This research covers 81 countries scattered on the six continents of the World. This sample is chosen randomly and it is intended to cover as many countries as possible with the required data available. The list of countries covered in this research is given in Appendix 1.

Data regarding the cultural dimension indexes of the countries are adopted from the website https://www.hofstede-insights.com/product/compare-countries/. The six cultural dimension indexes of the countries are listed on this website, indexes being between 0 and 100 . Categorization of countries on cultural dimensions basis is achieved by the criteria obtained from G. Hofstede support team. Entrepreneurial data of the countries within the scope of this study is obtained from the annual reports of GEDI. GEDI provides 3 sub-indexes, namely attitudes (ATT), abilities (ABT), aspirations (ASP) and an overall Global Entrepreneurship Index (GEI). Scores lie between 0 and 100. This study makes use of the Institute's entrepreneurial data for the years between 2013 and 2017 inclusive. Data regarding the economic development levels of the sample countries is obtained from the World Bank Database, which is mainly based on GDP per capita of the sample countries. Cultural and economic categorization of the countries presented in Appendix 2.

\subsection{Variables and model}

The cultural dimensions of the countries are the independent variables, namely, PD, IND, MAS, UA, LTO and IVR for the cultural dimensions Power Distance, Individualism, Masculinity, Uncertainty Avoidance, Long Term Orientation and Indulge vs. Restraint respectively. The dependent variables are the entrepreneurial indicators of the countries in the sample, namely; ATT, ABT, ASP, and GEI; for the Attitudes, Abilities, Aspirations and Global Entrepreneurship Indexes respectively. GDPMEAN is the mean of Gross Domestic Product Per Capita values (in USD) between the Years 2013-2017 (inclusive). This variable is used as the interacting variable between independent and dependent variables.

\subsection{Analysis}

The analysis' first objective to determine to determine the direction and magnitude of the cultural dimensions' effects on the entrepreneurial indicators of the countries. A Longitudinal General Least Squares (GLS), Random Effect (RE) four regression analyses are run, using with STATA since the dataset is longitudinal and the countries are randomly selected. The independent variables are the cultural dimensions, namely; PD, IND, MAS, UA, LTO, and IVR for all regressions. GEDI entrepreneurial indexes are the dependent variables, namely GEI, ASP, ATT, and ABT. The second step in the analysis is to check if there is an interaction between the influencing cultural dimensions and economic development level variable GDPMEAN on affecting GEI. This analysis is performed by using PROCESS ${ }^{\circ}$ macro for SPSS ${ }^{\circ}$. In this analysis, cultural dimensions are independent variables. GEI is the dependent variable and GDPMEAN acting as moderator. 


\section{Results}

\subsection{Longitudinal regression results}

The detailed results of Longitudinal GLS RE Regression analyses are presented in the Appendix. Regression models are all satisfactory $\left(\forall \chi^{2}: 98.78 \leq \chi^{2} \leq 200.30 ; \forall \mathrm{p}: \mathrm{p}<.005\right)$ and overall $\mathrm{R}^{2}\left(\mathrm{R}_{0}{ }^{2}\right)$ values are in the interval $\left(.550 \leq \mathrm{R}_{0}^{2} \leq .685\right)$. Below are the explanations for the longitudinal GLS RE regression analyses.

The unstandardized regression coefficients (b) for the independent variable PD have negative signs for all dependent variables which indicate a negative effect. But they are not significant $(\mathrm{p}>0.05)$, except for the dependent variable ABT $(\mathrm{p}=0.036)$. Thus, the hypothesis regarding the influence of $\mathrm{PD}$ on $\mathrm{ABT}, \mathrm{H}_{1 \mathrm{~b}}$ is supported, while $\mathrm{H}_{1 \mathrm{a}}, \mathrm{H}_{1 \mathrm{c}}$, and $\mathrm{H}_{1 \mathrm{~d}}$ are rejected. Power Distance seems to have almost no impact on entrepreneurial indicators except its negative influence on ABT.

The regression coefficient values for the variable IND have positive signs, and all are significant $(\forall \mathrm{p}$ : $\mathrm{p}<005)$. Thus, the hypotheses about this dimension $\mathrm{H}_{2 \mathrm{a}}, \mathrm{H}_{2 \mathrm{~b}}, \mathrm{H}_{2 \mathrm{c}}$, and $\mathrm{H}_{2 \mathrm{~d}}$ are all supported. Individualism has a positive impact on every aspect of entrepreneurial behavior.

The regression coefficient values for the independent variable MAS have negative signs and all are significant $(p<0.05)$, except for the dependent variable ASP $(p=0.453)$. MAS seems to have a negative influence on GEI, ABT, and ATT but no significant effect on ASP. All of the hypotheses regarding this dimension $\mathrm{H}_{3 \mathrm{a}}, \mathrm{H}_{3 \mathrm{~b}}, \mathrm{H}_{3 \mathrm{c}}$, and $\mathrm{H}_{3 \mathrm{~d}}$, assuming masculinity is a positive factor for entrepreneurship, are all rejected. On the contrary, Masculinity has a clear negative effect on entrepreneurship, since three out of four entrepreneurial indicators are affected by Masculinity in a rendering direction.

The Uncertainty Avoidance dimension variable UA has regression coefficient values which have positive and negative signs. None of the regression coefficients are significant ( $\forall \mathrm{p}$ : $\mathrm{p}>005)$. UA does not have any significant effect on entrepreneurial indicators. Thus, the hypotheses $\mathrm{H}_{4 \mathrm{a}}, \mathrm{H}_{4 \mathrm{~b}}, \mathrm{H}_{4 \mathrm{c}}$, and $\mathrm{H}_{4 \mathrm{~d}}$ are rejected.

The Long Term Orientation variable LTO has positive regression coefficient values and they are significant $(\forall \mathrm{p}: \mathrm{p}<.005)$. LTO has a definite positive effect on all entrepreneurial indicators. Thus, the hypothesis regarding this dimension $\mathrm{H}_{5 \mathrm{a}}, \mathrm{H}_{5 \mathrm{~b}}, \mathrm{H}_{5 \mathrm{c}}$, and $\mathrm{H}_{5 \mathrm{~d}}$ are all supported.

The final independent variable IVR has regression coefficient values with positive signs, and they are significant $(\mathrm{p}<0.05)$ except for the dependent variable ASP $(\mathrm{p}=0.084)$. It can be concluded from these results that IVR has a significant positive effect on GEI, ATT, and ABT, but not on ASP. Thus, the hypothesis $\mathrm{H}_{6 \mathrm{a}}, \mathrm{H}_{6 \mathrm{~b}}$, and $\mathrm{H}_{6 \mathrm{~d}}$ are supported, whereas $\mathrm{H}_{6 \mathrm{c}}$ is not supported. The summary of the GLS RE Longitudinal Regression results is presented in Table 1.

The longitudinal regression results are cross-checked with a different approach, with multiple linear regressions for each year by using IBM SPSS since there may be some inconsistencies due to temporal, conjectural or alike effects, and highly similar results have been obtained. 
Table 1. Effects of cultural dimensions on entrepreneurship, summary

\begin{tabular}{|l|l|l|l|l|}
\hline \multicolumn{1}{|c|}{$\begin{array}{c}\text { Cultural } \\
\text { Dimensions }\end{array}$} & \multicolumn{1}{|c|}{$\begin{array}{c}\text { Effect on entr. } \\
\text { attitudes (ATT) }\end{array}$} & $\begin{array}{c}\text { Effect on entr. } \\
\text { abilities (ABT) }\end{array}$ & $\begin{array}{c}\text { Effect on entr. } \\
\text { aspirations (ASP) }\end{array}$ & $\begin{array}{c}\text { Effect on overall } \\
\text { entr. success (GEI) }\end{array}$ \\
\hline Power Distance & $\begin{array}{l}\text { No significant } \\
\text { effect }\end{array}$ & Negative effect & $\begin{array}{l}\text { No significant } \\
\text { effect }\end{array}$ & No significant effect \\
\hline Individualism & Positive effect & Positive effect & Positive effect & Positive effect \\
\hline Masculinity & Negative effect & Negative Effect & $\begin{array}{l}\text { No significant } \\
\text { effect }\end{array}$ & Negative effect \\
\hline $\begin{array}{l}\text { Uncertainty } \\
\text { Avoidance }\end{array}$ & $\begin{array}{l}\text { No significant } \\
\text { effect }\end{array}$ & $\begin{array}{l}\text { No significant } \\
\text { effect }\end{array}$ & $\begin{array}{l}\text { No significant } \\
\text { effect }\end{array}$ & No significant effect \\
\hline $\begin{array}{l}\text { Long Term } \\
\text { Orientation }\end{array}$ & $\begin{array}{l}\text { No significant } \\
\text { effect }\end{array}$ & Positive effect & Positive effect & Positive effect \\
\hline $\begin{array}{l}\text { Indulgence vs. } \\
\text { Restraint }\end{array}$ & Positive effect & Positive effect & $\begin{array}{l}\text { No significant } \\
\text { effect }\end{array}$ & Positive effect \\
\hline
\end{tabular}

\subsection{Interaction analysis results}

The results of the PROCESS ${ }^{\circ}$ macro interaction analyses of IND, MAS, LTO, and IVR individually with GDPMEAN is presented in Table 2. The interaction effect of IND with GDPMEAN, IND ${ }^{*}$ GDPMEAN is significant $(\mathrm{F}=17.897, \mathrm{df} 1=1, \mathrm{df} 2=401, \mathrm{p}<0.05)$ but the contribution of this interaction to the explained variance is very small $\left(\Delta \mathrm{R}^{2}=0.011\right)$. For the interactions MAS*GDPMEAN and LTO ${ }^{*}$ GDPMEAN, similar results are obtained. Interaction is significant, but $\mathrm{R}^{2}$ change is negligible $(\mathrm{F}=4.848, \mathrm{df} 1=1, \mathrm{df} 2=401, \mathrm{p}<0.05$, $\Delta \mathrm{R}^{2}=0.004 ; \mathrm{F}=45.890, \mathrm{df} 1=1, \mathrm{df} 2=401, \mathrm{p}<0.05, \Delta \mathrm{R}^{2}=0.033$ respectively). The interaction effect $\mathrm{IVR}^{\star} \mathrm{GDPMEAN}$ is not significant $(\mathrm{F}=0.987, \mathrm{df} 1=1, \mathrm{df} 2=401, \mathrm{p}>0.05)$.

Therefore, we can conclude that some cultural dimensions do interact with economic development levels on impacting entrepreneurship, but the effects generated are quite small.

Table 2. Results of interaction analyses

\begin{tabular}{|l|c|c|c|c|c|}
\hline \multicolumn{1}{|c|}{ Interaction terms } & $\mathrm{F}$ & $\mathrm{df} 1$ & $\mathrm{df} 2$ & $\mathrm{p}$ & $\Delta \mathrm{R}^{2}$ \\
\hline IND $^{\star}$ GDPMEAN & 17.897 & 1 & 401 & 0.000 & 0.011 \\
\hline $\mathrm{MAS}^{\star}$ GDPMEAN & 4.848 & 1 & 401 & 0.028 & 0.004 \\
\hline LTO $^{\star}$ GDPMEAN & 45.890 & 1 & 401 & 0.000 & 0.033 \\
\hline IVR $^{\star}$ GDPMEAN & 0.987 & 1 & 401 & 0.320 & 0.000 \\
\hline
\end{tabular}

\section{Discussion}

In this longitudinal study, culture has been considered culture as a national level variable since it is empirically supported that culture is a valid concept (Minkov \& Hofstede, 2012) but this study explicitly reveals that culture is also a very complicated concept and cannot be explained by simple characteristics. Prior to hypothesis formulation, the relevant theories and empirical studies in the field of entrepreneurship and culture have been examined, yet profoundly different and surprising results have been obtained. 
The cultural dimension of Power Distance is generally associated with entrepreneurship in a rendering manner. But the results indicate that the effect is negligible. This may arise from the truth that high power distance countries are also aware of the importance of entrepreneurship and define their policies accordingly. Another explanation may be that members of high power distance societies may desire to become entrepreneurs to achieve their aspirations (dissatisfaction hypothesis). Relevant theory and empirical studies indicate that Individualism is a supportive dimension for entrepreneurship. The results obtained corroborate previous studies.

The masculinity dimension is generally thought to influence entrepreneurship in a positive manner, but the results obtained indicate just the opposite. Masculinity seems to render entrepreneurship. One possible explanation is that strict sharing of the roles in high masculinity countries may lead to putting almost half of the country's population away from professional business life. This attitude may limit society to use human resources effectively. Another explanation may be that, with the new global economy, customers are more conscious about the products, services, market, prices, and competition. They have much more options to choose from. So they also expect quality, tenderness, and care in customer relations which indeed are feminine values.

Uncertainty Avoidance is considered to be negatively associated with entrepreneurship because risk and uncertainty are generally related to the nature of entrepreneurship. The results indicate that the Uncertainty Avoidance dimension is not significant in any aspect of entrepreneurship. One explanation may be that individuals and business owners find ways to minimize the risk in their entrepreneurial decisions in this type of countries (e.g. Corporate Entrepreneurship, spin-off's, joint ventures, and angel investors).

It has been hypothesized that Long-Term Orientation is supportive of entrepreneurship, and the results obtained are as expected. Since entrepreneurs are "dreamers" in a sense, they are naturally long term oriented. Although Indulge vs. Restraint Dimension is the newest and least studied dimension, its effect on entrepreneurship is quite remarkable and evident. This dimension is thought to be associated with individualism and the search for happiness which is a state that may be achieved by entrepreneurship.

The results of the interaction analysis imply that the cultural dimensions Individualism, Masculinity, and Long Term Orientation interact with economic development levels of the countries on impacting the entrepreneurship success rates but the interaction effect is not striking. Both culture and economic development level are important determinants of entrepreneurship, but they do not seem to be interacting with each other.

\section{Conclusions}

This study has clearly shown that culture impacts the entrepreneurship ecology in a country with very surprising results. The Cultural Dimension Power is generally considered to render entrepreneurship the findings of this study show that it has no significant effect. The cultural dimension Masculinity is accepted as a positive factor, but the findings of this study indicate just the opposite. The Uncertainty Avoidance dimension is generally taught to render entrepreneurship, but the findings indicate that it has no significant effect, and finally the 
new cultural dimension Indulgence has been found to be strongly supporting entrepreneurship. Findings on the cultural dimensions Individualism and Long Term Orientation support previous findings that these dimensions support entrepreneurship. There has not been found any evidence of a strong interaction effect of culture and economic development on entrepreneurship.

There are several unique contributions to the entrepreneurship literature in this research. One of them is the longitudinal study which spans through five consecutive years. Second, a multidimensional concept of culture is used, and the relatively new dimensions -e.g., Indulgence vs. Restraint- are included in the analysis together with the relatively older ones. Another contribution is that its sample covers 81 countries which are more comprehensive than previous studies. The GEDI measurement method of entrepreneurship success encompasses all aspects of entrepreneurship and empirical studies using this method are scarce. As one factor cannot explain a complex and elusive phenomenon like entrepreneurship, interaction with economic development level parameters is also analyzed. As in almost every study, this study has also certain limitations. One of them is the time period, which is limited to five years, is not well enough for a longitudinal study. The second one is the size of the sample. Data regarding culture and entrepreneurship is not available for many countries. As more data is accumulated in time, this study may be repeated and more precise and detailed results may be obtained. Finally, although there are good reasons to structure the study on the Hofstede approach for dimensionalizing a national culture, this approach is not the sole alternative and has its own limitations. The results obtained may be somehow contradictory and provocative for further study. It is believed that this paper will fill some crucial gaps in the entrepreneurship field and open new avenues for scholars of entrepreneurship, practitioners, and policymakers.

\section{References}

Acs, Z. J., Szerb, L., \& Lloyd, A. (2018). Global Entrepreneurship Index 2018. The Global Entrepreneurship and Development Institute. Washington, DC. https://doi.org/10.1007/978-3-030-03279-1

Acs, Z. J., Audretsch, D. B., \& Evans, D. S. (1992). The determinants of variations in self-employment rates across countries and over time. WZB.

Ahl, H. (2006). Why research on women entrepreneurs needs new directions. Entrepreneurship Theory and Practice, 30(5), 595-621. https://doi.org/10.1111/j.1540-6520.2006.00138.x

Allred, B. B., \& Swan, K. S. (2004). Global versus multidomestic: Culture's consequences on innovation. Management International Review, 81-105. Gabler Werlag, Wiesbaden. https://doi.org/10.1007/978-3-322-90999-2_5

Amiri, S., \& Marimaei, M. (2012). The concept of entrepreneurship and entrepreneurs traits and characteristics. Scholarly Journal of Business Administration, 27, 150-155.

Au, K., Han, S., \& Chung, H. M. (2018). The impact of sociocultural context on strategic renewal: A twenty-six nation analysis of family firms. Cross Cultural \& Strategic Management, 25(4), 604-627. https://doi.org/10.1108/CCSM-07-2017-0090

Audretsch, D. B., Carree, M. A., \& Thurik, A. R. (2001). Does entrepreneurship reduce unemployment? Tinbergen Institute discussion paper, 01-074/3. 
Audretsch, D. B., Thurik, R., Verheul, I., \& Wennekers, S. (2002). Entrepreneurship: determinants and policy in a European-US comparison (Vol. 27). Springer Science \& Business Media. https://doi.org/10.1007/b109395

Autio, E., Pathak, S., \& Wennberg, K. (2013). Consequences of cultural practices for entrepreneurial behaviors. Journal of International Business Studies, 44(4), 334-362. https://doi.org/10.1057/jibs.2013.15

Baughn, C. C., \& Neupert, K. E. (2003). Culture and national conditions facilitating entrepreneurial start-ups. Journal of International Entrepreneurship, 1(3), 313-330. https://doi.org/10.1023/A:1024166923988

Bogatyreva, K., Edelman, L. F., Manolova, T. S., Osiyevskyy, O., \& Shirokova, G. (2019). When do entrepreneurial intentions lead to actions? The role of national culture. Journal of Business Research, 96, 309-321. https://doi.org/10.1016/j.jbusres.2018.11.034

Bond, M. H., Leung, K., Au, A., Tong, K. K., De Carrasquel, S. R., Murakami, F., Yamaguchi, S., et al. (2004). Culture-level dimensions of social axioms and their correlates across 41 cultures. Journal of Cross-Cultural Psychology, 35(5), 548-570. https://doi.org/10.1177/0022022104268388

Bula, H. O. (2012). Performance of women in Small Scale Enterprises (SSEs): marital status and family characteristics. European Journal of Business and Management, 4(7), 85-99.

Busenitz, L. W., \& Lau, C. M. (1996). A cross-cultural cognitive model of new venture creation. Entrepreneurship Theory and Practice, 20(4), 25-40. https://doi.org/10.1177/104225879602000403

Cacciotti, G., \& Hayton, J. (2017). National culture and entrepreneurship. In G. Ahmetoglu, T. Chamorro-Premuzic, B. Klinger, \& T. Karcisky (Ed.s), The Wiley handbook of entrepreneurship (pp. 401422). Wiley Blackwell. https://doi.org/10.1002/9781118970812.ch18

Carayannis, E. G. (2013). Encyclopedia of creativity, invention, innovation, and entrepreneurship. Springer. https://doi.org/10.1007/978-1-4614-3858-8

Coulibaly, S. K., Erbao, C., \& Mekongcho, T. M. (2018). Economic globalization, entrepreneurship, and development. Technological Forecasting and Social Change, 127, 271-280. https://doi.org/10.1016/j.techfore.2017.09.028

Davidsson, P., \& Wiklund, J. (1997). Values, beliefs and regional variations in new firm formation rates. Journal of Economic Psychology, 18(2-3), 179-199. https://doi.org/10.1016/S0167-4870(97)00004-4

Dheer, R. J. (2017). Cross-national differences in entrepreneurial activity: role of culture and institutional factors. Small Business Economics, 48(4), 813-842.

Etzioni, A. (1987). Entrepreneurship, adaptation and legitimation: a macro-behavioral perspective. Journal of Economic Behavior \& Organization, 8(2), 175-189.

https://doi.org/10.1016/0167-2681(87)90002-3

Fiet, J. O. (2002). The systematic search for entrepreneurial discoveries. ABC-CLIO.

Frederking, L. C. (2004). A cross-national study of culture, organization, and entrepreneurship in three neighborhoods. Entrepreneurship \& Regional Development, 16(3), 197-215. https://doi.org/10.1080/0898562042000197126

Freytag, A., \& Thurik, R. (2007). Entrepreneurship and its determinants in a cross-country setting. Journal of Evolutionary Economics, 17(2), 117-131. https://doi.org/10.1007/s00191-006-0044-2

Galvão, A., Mascarenhas, C., Gouveia Rodrigues, R., Marques, C. S., \& Leal, C. T. (2017). A quadruple helix model of entrepreneurship, innovation, and stages of economic development. Review of International Business and Strategy, 27(2), 261-282. https://doi.org/10.1108/RIBS-01-2017-0003

Gartner, W. B. (1988). Who is an entrepreneur? Is the wrong question. American Journal of Small Business, 12(4), 11-32. https://doi.org/10.1177/104225878801200401 
Gupta, V. K., Turban, D. B., Wasti, S. A., \& Sikdar, A. (2009). The role of gender stereotypes in the perceptions of entrepreneurs and intentions to become an entrepreneur. Entrepreneurship Theory and Practice, 33(2), 397-417. https://doi.org/10.1111/j.1540-6520.2009.00296.x

Harutyunyan, A., \& Özak, Ö. (2017). Culture, diffusion, and economic development: The problem of observational equivalence. Economics Letters, 158, 94-100.

https://doi.org/10.1016/j.econlet.2017.06.040

Hayton, J. C., \& Cacciotti, G. (2013). Is there an entrepreneurial culture? A review of empirical research. Entrepreneurship \& Regional Development, 25(9-10), 708-731. https://doi.org/10.1080/08985626.2013.862962

Hayton, J. C., George, G., \& Zahra, S. A. (2002). National culture and entrepreneurship: A review of behavioral research. Entrepreneurship Theory and Practice, 26(4), 33-52. https://doi.org/10.1177/104225870202600403

Hechavarria, D. M., \& Reynolds, P. D. (2009). Cultural norms \& business start-ups: the impact of national values on opportunity and necessity entrepreneurs. International Entrepreneurship and Management Journal, 5(4), 417. https://doi.org/10.1007/s11365-009-0115-6

Hofstede, G. (1980). Culture's consequences: International Differences in Work-Related Values. Newbury Park, CA, Sage Publications.

Hofstede, G. (2001). Culture's consequences: comparing values, behaviors, institutions, and organizations across nations. Thousand Oaks, C, Sage Publications.

Hofstede, G. (2010). The GLOBE debate: Back to relevance. Journal of International Business Studies, 41(8), 1339-1346. https://doi.org/10.1057/jibs.2010.31

Hofstede, G. (2011). Dimensionalizing cultures: The Hofstede model in context. Online Readings in Psychology and Culture, 2(1), 8. https://doi.org/10.9707/2307-0919.1014

Hofstede, G., \& Bond, M. H. (1988). The Confucius connection: From cultural roots to economic growth. Organizational Dynamics, 16(4), 5-21. https://doi.org/10.1016/0090-2616(88)90009-5

Hofstede, G., Noorderhaven, N. G., Thurik, A. R., Uhlaner, L. M., Wennekers, A. R., \& Wildeman, R. E. (2004). Culture's role in entrepreneurship: self-employment out of dissatisfaction. In T. E. Brown, \& I. Ulijn (Ed's), Innovation, entrepreneurship, and culture: The interaction between technology, progress, and economic growth (pp. 162-203). Edward Elgar Publishing Limited. https://doi.org/10.4337/9781845420550.00014

Hofstede, G. H., Hofstede, G. J., \& Minkov, M. (2010). Cultures and organizations: Software of the mind. Maidenhead, McGraw-Hill.

House, R. J., Hanges, P. J., Javidan, M., Dorfman, P. W., \& Gupta, V. (2004). Culture, leadership, and organizations: The GLOBE study of 62 societies. Sage publications.

Hui, C. H., \& Triandis, H. C. (1986). Individualism-collectivism: A study of cross-cultural researchers. Journal of cross-cultural psychology, 17(2), 225-248. https://doi.org/10.1177/0022002186017002006

Huntington, S. P. (1997). The clash of civilizations and the remaking of world order. Penguin Books India.

Inglehart, R. (1997). Modernization and postmodernization: Cultural, economic, and political change in 43 societies. Princeton University Press.

Kelley, D. J., Singer, S., \& Herrington, M. (2012). 2011 Global Report. Global Entrepreneurship Monitor, London Business School. London.

Kirkman, B. L., Lowe, K. B., \& Gibson, C. B. (2006). A quarter century of culture's consequences: A review of empirical research incorporating Hofstede's cultural values framework. Journal of International Business Studies, 37(3), 285-320. https://doi.org/10.1057/palgrave.jibs.8400202

Kreiser, P. M., Marino, L. D., Dickson, P., \& Weaver, K. M. (2010). Cultural influences on entrepreneurial orientation: The impact of national culture on risk taking and proactiveness in SMEs. Entrepreneurship Theory and Practice, 34(5), 959-983. https://doi.org/10.1111/j.1540-6520.2010.00396.x 
Krueger, N., Liñán, F., \& Nabi, G. (2013). Cultural values and entrepreneurship. Entrepreneurship \& Regional Development, 25(9-10), 213-245. https://doi.org/10.1080/08985626.2013.862961

Kuratko, D. F. (2003). Entrepreneurship education: Emerging trends and challenges for the 21st century. White Paper, US Association of Small Business Education, 22.

Kuratko, D. F. (2007). Entrepreneurial leadership in the 21st century: Guest editor's perspective. Journal of Leadership \& Organizational Studies, 13(4), 1-11. https://doi.org/10.1177/10717919070130040201

Laffranchini, G., Kim, S. H., \& Posthuma, R. A. (2018). A metacultural approach to predicting self-employment across the globe. International Business Review, 27(2), 481-500. https://doi.org/10.1016/j.ibusrev.2017.10.001

Landes, D. S. (1998). The wealth and poverty of nations: Why are some so rich and others so poor. W. W. Norton \& Company Ltd. London.

Lin, L. H. (2009). Effects of national culture on process management and technological innovation. Total Quality Management, 20(12), 1287-1301. https://doi.org/10.1080/14783360903250621

Mair, J., \& Marti, I. (2006). Social entrepreneurship research: A source of explanation, prediction, and delight. Journal of World Business, 41(1), 36-44. https://doi.org/10.1016/j.jwb.2005.09.002

McClelland, D. C. (1961). The achieving society. Princeton, NJ, D. Van Norstrand Company. Inc. https://doi.org/10.1037/14359-000

McDougall, P. P., \& B. M. Oviatt. (2000). International entrepreneurship: the intersection of two research paths. Academy of Management Journal, 43(5), 902-906. https://doi.org/10.2307/1556418

McGrath, R. G., MacMillan, I. C., Yang, E. A. Y., \& Tsai, W. (1992). Does culture endure, or is it malleable? Issues for entrepreneurial economic development. Journal of Business Venturing, 7(6), 441458. https://doi.org/10.1016/0883-9026(92)90019-N

McGrath, R. G., MacMillan, L. C., \& Scheinberg, S. (1992). Elitists, risk-takers, and rugged individualists? An exploratory analysis of cultural differences between entrepreneurs and non-entrepreneurs. Journal of business venturing, 7(2), 115-135. https://doi.org/10.1016/0883-9026(92)90008-F

Minkov, M., \& Hofstede, G. (2012). Is national culture a meaningful concept? Cultural values delineate homogeneous national clusters of in-country regions. Cross Cultural Research, 46(2), 133-159. https://doi.org/10.1177/1069397111427262

Minkov, M. (2009). Predictors of differences in subjective well-being across 97 nations. Cross-Cultural Research, 43(2), 152-179. https://doi.org/10.1177/1069397109332239

Minniti, M., Bygrave, W. D., \& Autio, E. (2006). Global entrepreneurship monitor: 2005 Executive Report. Global Entrepreneurship Monitor. London Business School.

Minniti, M., Bygrave, W. D., \& Autio, E. (2005). Global entrepreneurship monitor. 2004 Report on Women and Entrepreneurship. Global Entrepreneurship Monitor. London Business School.

Mitchell, R. K., Smith, B., Seawright, K. W., \& Morse, E. A. (2000). Cross-cultural cognitions and the venture creation decision. Academy of Management Journal, 43(5), 974-993. https://doi.org/10.2307/1556422

Morris, M. H., Avila, R. A., \& Allen, J. (1993). Individualism and the modern corporation: Implications for innovation and entrepreneurship. Journal of Management, 19(3), 595-612. https://doi.org/10.1177/014920639301900305

Morris, M. H., Kuratko, D. F., \& Covin, J. G. (2010). Corporate entrepreneurship \& innovation. Cengage Learning.

Mueller, S. L., \& Thomas, A. S. (2001). Culture and entrepreneurial potential: A nine country study of locus of control and innovativeness. Journal of Business Venturing, 16(1), 51-75.

https://doi.org/10.1016/S0883-9026(99)00039-7 
Nicolás, C., Rubio, A., \& Fernández-Laviada, A. (2018). Cognitive determinants of social entrepreneurship: Variations according to the degree of economic development. Journal of Social Entrepreneurship, 9(2), 154-168. https://doi.org/10.1080/19420676.2018.1452280

Osoba, B. J. (2009). Culture and entrepreneurial activity in the United States: A quantitative analysis. Innovation - The European Journal of Social Science Research, 22(3), 341-370. https://doi.org/10.1080/13511610903367820

Pinillos, M. J., \& Reyes, L. (2011). The relationship between individualist-collectivist culture and entrepreneurial activity: evidence from Global Entrepreneurship Monitor data. Small Business Economics, 37(1), 23-37. https://doi.org/10.1007/s11187-009-9230-6

Ralston, D. A., Holt, D. H., Terpstra, R. H., \& Kai-Cheng, Y. (1997). The impact of natural culture and economic ideology on managerial work values: a study of the United States, Russia, Japan, and China. Journal of International Business Studies, 28(1), 177-207. https://doi.org/10.1057/palgrave.jibs. 8490097

Schumpeter, J. A. (1934). The schumpttr: Theory of economic development. Harvard University Press.

Schwartz, S. H. (1994). Beyond individualism/collectivism: New cultural dimensions of values. Sage Publications, Inc.

Shane, S., Venkataraman, S., \& MacMillan, I. (1995). Cultural differences in innovation championing strategies. Journal of Management, 21(5), 931-952. https://doi.org/10.1177/014920639502100507

Shane, S., \& Venkataraman, S. (2000). The promise of entrepreneurship as a field of research. Academy of Management Review, 25(1), 217-226. https://doi.org/10.5465/amr.2000.2791611

Shane, S. (1992). Why do some societies invent more than others? Journal of Business Venturing, 7(1), 29-46. https://doi.org/10.1016/0883-9026(92)90033-N

Shane, S. (1993). Cultural influences on national rates of innovation. Journal of Business Venturing, 8(1), 59-73. https://doi.org/10.1016/0883-9026(93)90011-S

Shane, S. (1996). Explaining variation in rates of entrepreneurship in the United States: 1899-1988. Journal of Management, 22(5), 747-781. https://doi.org/10.1016/S0149-2063(96)90021-5

Shane, S. (2008). The illusions of entrepreneurship: The costly myths that entrepreneurs, investors, and policy makers live by. Yale University Press.

Shapero, A., \& Sokol, L. (1982). The social dimensions of entrepreneurship. In C. Kent, L. Sexton, \& K. Vesper (Ed.s), Encylopedia of Entrepreneurship (pp. 72-90). Englewood Cliffs, NJ, Prentice Hall.

Soares, A. M., Farhangmehr, M., \& Shoham, Aç. (2007). Hofstede's dimensions of culture in international marketing studies. Journal of Business Research, 60(3), 277-284. https://doi.org/10.1016/j.jbusres.2006.10.018

Suddle, K., Beugelsdijk, S., \& Wennekers, S. (2010). Entrepreneurial culture and its effect on the rate of nascent entrepreneurship. In Entrepreneurship and Culture, 227-244. Springer, Berlin, Heidelberg. https://doi.org/10.1007/978-3-540-87910-7_11

Swierczek, F. W., \& Quang, T. (2004). Entrepreneurial cultures in Asia: Business policy or cultural imperative. Journal of Enterprising Culture, 12(02), 127-145. https://doi.org/10.1142/S0218495804000075

Tiessen, J. H. (1997). Individualism, collectivism, and entrepreneurship: A framework for international comparative research. Journal of Business Venturing, 12(5), 367-384. https://doi.org/10.1016/S0883-9026(97)81199-8

Uhlaner, L., \& Thurik, R (2007). Postmaterialism influencing total entrepreneurial activity across nations. Journal of Evolutionary Economics, 17(2), 161-185. https://doi.org/10.1007/s00191-006-0046-0

Van Everdingen, Y. M., \& Waarts, E. (2003). The effect of national culture on the adoption of innovations. Marketing Letters, 14(3), 217-232. https://doi.org/10.1023/A:1027452919403

Weber, M. (1930). The protestant ethic and the spirit of capitalism. Route Edge. 
Wennekers, S. A. (2006). Entrepreneurship at country level: economic and non-economic determinants (No. 81). Rotterdam.

Wennekers, S., Van Wennekers, A., Thurik, R., \& Reynolds, P. (2005). Nascent entrepreneurship and the level of economic development. Small Business Economics, 24(3), 293-309. https://doi.org/10.1007/s11187-005-1994-8

Wennekers, S., Thurik, R., van Stel, A., \& Noorderhaven, N. (2007). Uncertainty avoidance and the rate of business ownership across 21 OECD countries, 1976-2004. Journal of Evolutionary Economics, 17(2), 133-160. https://doi.org/10.1007/s00191-006-0045-1

$\mathrm{Wu}, \mathrm{S}$. (2007). The relationship between national culture and national entrepreneurial activity. World Review of Entrepreneurship, Management and Sustainable Development, 3(2), 127-141.

https://doi.org/10.1504/WREMSD.2007.013607 


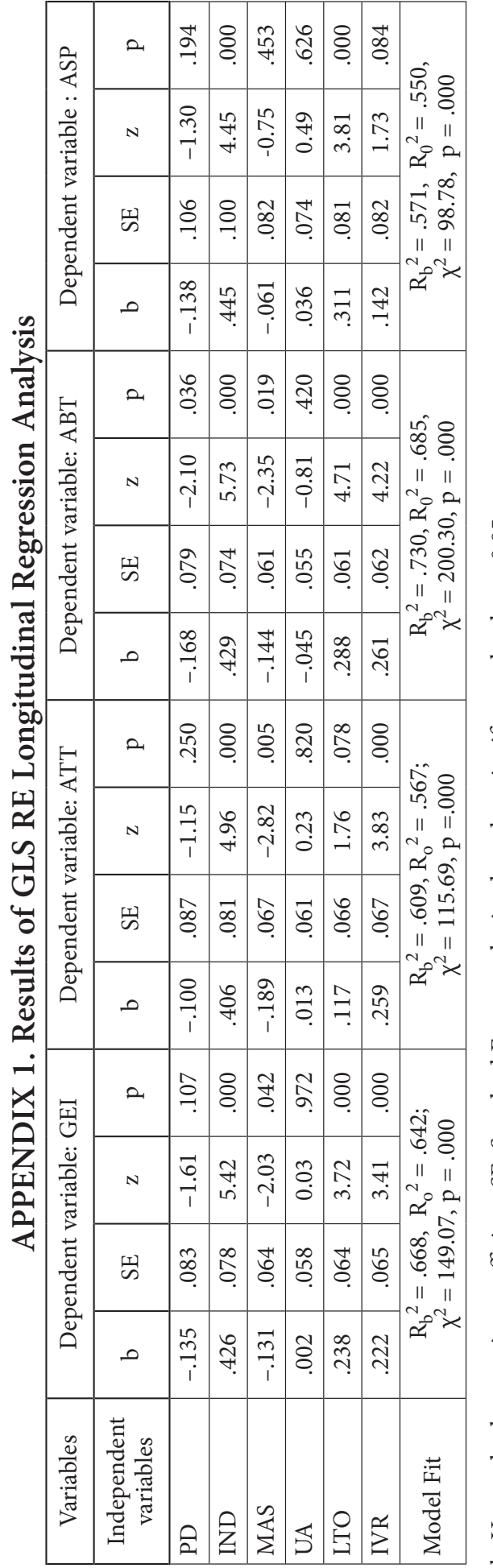

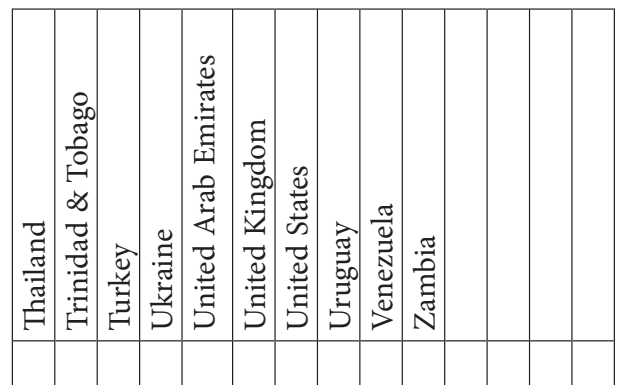

농

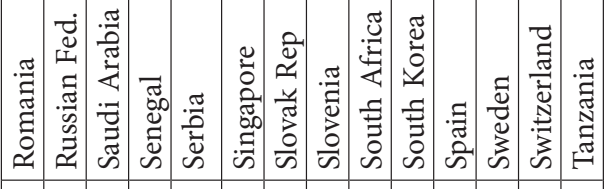

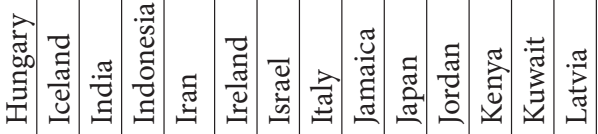
वे|

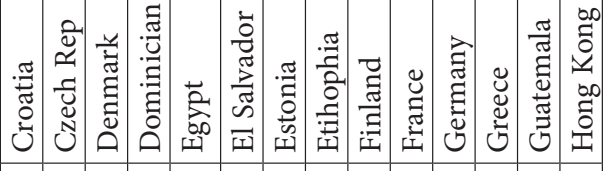
도

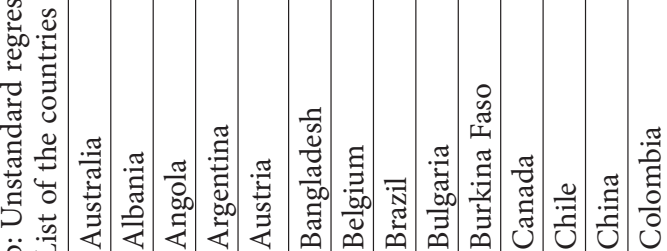


APPENDIX 2. Cultural and Economic Level Groupings*

\begin{tabular}{|c|c|c|c|c|c|c|c|}
\hline ID & Country & WB4 & $\mathrm{PD}$ & IND & MAS & LTO & IVR \\
\hline 1 & Australia & 4 & 1 & 3 & 3 & 1 & 3 \\
\hline 2 & Austria & 4 & 1 & 2 & 3 & 3 & 3 \\
\hline 3 & Belgium & 4 & 3 & 3 & 2 & 3 & 2 \\
\hline 4 & Canada & 4 & 1 & 3 & 2 & 1 & 3 \\
\hline 5 & Chile & 4 & 3 & 1 & 1 & 1 & 3 \\
\hline 6 & Czech Rep & 4 & 2 & 2 & 2 & 3 & 1 \\
\hline 7 & Denmark & 4 & 1 & 3 & 1 & 1 & 3 \\
\hline 8 & Estonia & 4 & 2 & 2 & 1 & 3 & 1 \\
\hline 9 & Finland & 4 & 1 & 3 & 1 & 1 & 2 \\
\hline 10 & France & 4 & 3 & 3 & 2 & 3 & 2 \\
\hline 11 & Germany & 4 & 1 & 3 & 3 & 3 & 2 \\
\hline 12 & Greece & 4 & 2 & 1 & 2 & 2 & 2 \\
\hline 13 & Hungary & 4 & 2 & 3 & 3 & 2 & 1 \\
\hline 14 & Iceland & 4 & 1 & 2 & 1 & 1 & 3 \\
\hline 15 & Ireland & 4 & 1 & 3 & 3 & 1 & 3 \\
\hline 16 & Israel & 4 & 1 & 2 & 2 & 1 & 2 \\
\hline 17 & Italy & 4 & 2 & 3 & 3 & 3 & 1 \\
\hline 18 & Japan & 4 & 2 & 2 & 3 & 3 & 2 \\
\hline 19 & South Korea & 4 & 2 & 1 & 1 & 3 & 1 \\
\hline 20 & Latvia & 4 & 2 & 3 & 1 & 3 & 1 \\
\hline 21 & Luxembourg & 4 & 2 & 2 & 2 & 3 & 2 \\
\hline 22 & Mexico & 3 & 3 & 1 & 3 & 1 & 3 \\
\hline 23 & Netherlands & 4 & 1 & 3 & 1 & 3 & 3 \\
\hline 24 & Norway & 4 & 1 & 3 & 1 & 1 & 2 \\
\hline 25 & Poland & 4 & 3 & 2 & 3 & 1 & 1 \\
\hline 26 & Portugal & 4 & 3 & 1 & 1 & 1 & 1 \\
\hline 27 & Slovak Rep & 4 & 3 & 2 & 3 & 3 & 1 \\
\hline 28 & Slovenia & 4 & 3 & 1 & 1 & 2 & 2 \\
\hline 29 & Spain & 4 & 2 & 2 & 2 & 2 & 2 \\
\hline 30 & Sweden & 4 & 1 & 3 & 1 & 2 & 3 \\
\hline 31 & Switzerland & 4 & 1 & 3 & 3 & 3 & 3 \\
\hline 32 & Turkey & 3 & 3 & 1 & 2 & 2 & 2 \\
\hline 33 & United Kingdom & 4 & 1 & 3 & 3 & 2 & 3 \\
\hline 34 & United States & 4 & 2 & 3 & 3 & 1 & 3 \\
\hline 35 & Iran & 3 & 2 & 2 & 2 & 1 & 2 \\
\hline 36 & Brazil & 3 & 3 & 1 & 2 & 2 & 2 \\
\hline 37 & Peru & 3 & 3 & 1 & 2 & 1 & 2 \\
\hline 38 & Venezuela & 3 & 3 & 1 & 3 & 1 & 3 \\
\hline
\end{tabular}

